\title{
Humility in Islamic Contemplative Ethics
}

\author{
Atif Khalil \\ Religious Studies Department, University of Lethbridge, Lethbridge, Alberta, \\ Canada \\ atif.khalil@uleth.ca
}

\begin{abstract}
From the origins of Islamic history, humility (khushū'/tawāduc) has occupied a central place in Muslim piety. This has been in large part due to its defining role in the Qurān and hadìths, and no less because it stands as the opposite of pride (kibr) - the cardinal sin of both Iblīs and Pharaoh in Scripture. By drawing on the literature of Sufism or tașawwuf from its formative period to the 2oth century-spanning the writings of such figures as al-Makkī (d. 386/996), al-Qushayrī (d. 465/1072), Ibn al-'Arabī (d. 638/1240), Rūmī (d. 672/1273), al-Sha'rānī (d. 973/1565), al-Darqāwī (d. 1239/1823), and al-Sharnūbī (d. 1348/1929) — the article examines the defining characteristics of this virtue, its marks or signs, and the dangers that lie in its embodiment. In the process, we shall see how humility occupies a place somewhere in between pride, conceit, and self-admiration, on the one hand, and self-loathing, self-denigration, and outright self-hatred, on the other. Although humility is, in theory, to be exercised towards both God and other human beings, the precise nature of its embodiment, as we might expect, varies in relation to both. The article ends with an epilogue on what it means to transcend humility altogether.
\end{abstract}

\section{Keywords}

humility - pride - Sufi ethics - Islamic ethics - virtue ethics - virtue theory - moral psychology - Islamic mysticism - Sufism - khushūe - tawā

* For their critical feedback on an earlier draft of the article, I would like to express my heartfelt gratitude to C. Charissage, C. Dagli, K. Reinhart, N. Sedek, A. Shaker, E. Winkel, C. Zargar and JIE's peer-reviewers. This modest scholarly contribution is dedicated to the memory of Laleh Bakhtiar (1938-2020), a pioneer in the field of modern Sufi psychology and ethics. 


\section{انلمان|}

تحتل فضيلة التواضع أو الخشوع المكانة الأسمى في منظومة التدين الإسلامي من الفترة التأسيسية للتاريخ

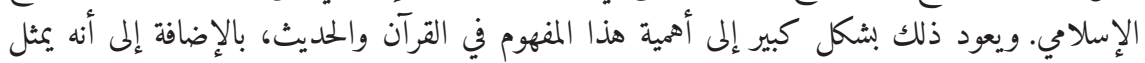

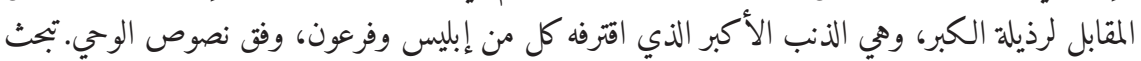

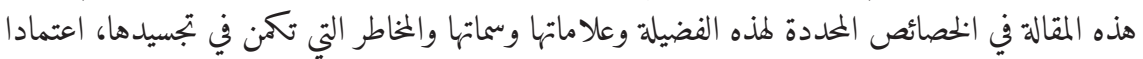

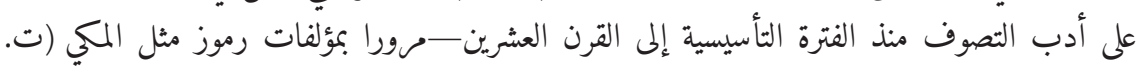
(ب6)386) والقشيري (ت. (ت.

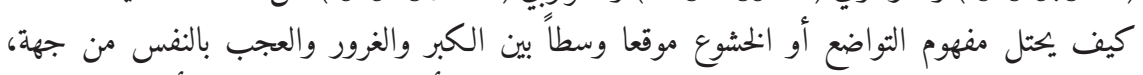

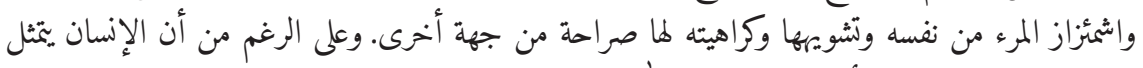

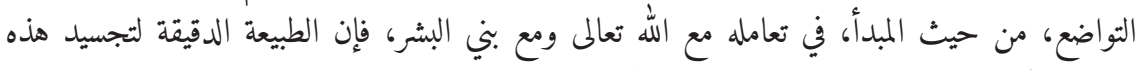

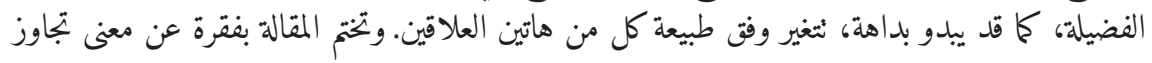
التواضع كليا.

\section{الكملات المفتاحية}

التواضع - الخشوع - الكبر - العجب - الأخلاق الصوفية - الأخلاق الإسلامية - أخلاق الفضيلة -

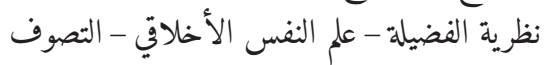

And (for) humble men and humble women ...

He has prepared forgiveness and a magnificent reward.

QUR'ĀN 33:35

The believer does not humiliate himself.

HADİTH 


\section{Introduction}

At risk of oversimplification, it can be argued that there have been three approaches to humility in Western ethics. The first placed it near the very epicentre of moral life, and usually associated it with feelings of lowliness and meekness, rooted in a simultaneous recognition of one's vile or defiled nature and the grandeur and majesty of God. Often, though not necessarily, this perspective was the outgrowth of a certain mode of theological reflection focused on the fallen nature of the human being, original sin, a Manichean-like attitude that relegated the body and its appetites to objects of shame and reproach, a self-lacerating piety that found the soul's salvation in its subjugation and denigration, or a combination of any of the above. Partly as a response to more extreme articulations of this view, there arose a countervailing perspective that found little to no merit in the virtue at all, and gained momentum particularly after the Enlightenment, when the higher power toward whom humility was to be principally exercised began to recede into the background, eventually disappearing altogether. While traces of this view can be found among the ancient philosophers as well, especially Aristotle, for whom magnanimity prevented humility from obtaining the status of a moral good, with the advent of modernity humility lost the eminence of place it once occupied in Western virtue theory. There seemed to be little value for critics of humility, stretching from Montaigne and Spinoza to Hume and Nietzsche, in nurturing a quality that extolled lowliness, inferiority, and ignobleness, and that stood as an obstacle to acquiring an accurate idea of one's own worth (see Button 2005, 840-844). The reasons for this displacement were poignantly summarised by Hare, a contemporary moral philosopher, when he observed of modern virtue ethics, that it has been "largely indifferent or even hostile to the character disposition of humility. The term for many denotes low self-regard or meekness, and it is hard to see what is beneficial to oneself or society as a whole in a tendency to dismiss whatever strengths one does have, especially if this is coupled with permissiveness towards contemptuous treatment at the hands of others" (Hare 1996, 235; cf. Richards 1988, 253).

But Hare also drew attention to the attempts of at least some contemporary ethicists to revive and rehabilitate humility by redefining it. As opposed to underestimating the value of the self, some have shifted its accent to "nonoverestimation." Along similar lines, others have proposed that the central features of the virtue - when it is a virtue - should lie in the extent to which it creates a disposition to acknowledge one's limitations, mistakes and imperfections; fosters an openness to new ideas, advice and even criticism; and removes 
a desire to "self-enhance," or make oneself appear better or more accomplished than one actually is (the equivalent, in many respects, of padding up a resume). Perhaps the most notable proponents of this third view are Nadelhoffer and Wright (2017a, 309-342; 2017b, 168-200). Like critics of humility, they find conceptualisations of the virtue that emphasise self-abasement wanting and deficient. While they recognise that a healthy sense of self demands a measure of self-worth, dignity and self-esteem, the cultivation of humility, in their eyes, helps correct and balance an inborn, innate tendency we have as human beings to place ourselves at the centre of the universe and prioritise our own needs above those of others (2017a, 316).

When we consider Islamic conceptions of humility, ${ }^{1}$ especially through the lens of its inward-turning, contemplative tradition of tașawwuf, or Sufism (often defined as Islamic mysticism), ${ }^{2}$ it becomes clear that while the character trait stands as a virtue the merits of which are lauded in the Qurān, the

1 To date there has been next to nothing published in English on humility in Islam. Neither the Brill Encyclopaedia of Islam nor Encyclopaedia of the Qur'ān have articles on the subject. Mohammed Rustom's recent translation of al-Ghazālīs (d. 505/1111) Kitāb Dhamm alKibr wa-l-Ujb ("On Condemnation of Pride and Self-Admiration") contains a chapter on humility (2018, 15-25). Al-Qushayrīs (d. 465/1072) Risāla ("Epistle") also includes a short section devoted to the subject (2002, 287-296). A partial English edition of this early Sufi text was produced by Barbara von Schlegel (1990), with full translations following later by Rabia T. Harris (2000) and then Alexander Knysh (2007). The chapter on humility is found in all of them.

2 We must take seriously the claim of Marshall Hodgson, that if "one must consciously choose and face the implications of one's approach to a civilisation, so must one also choose and face the implications of one's terms, selecting them relevant to the questions one is asking" $(1974,1: 45)$. Scholarship to date is divided on how best to classify Sufism. Some prefer the designation "Islamic mysticism," while for others it obfuscates the phenomenon more than it clarifies it. The same may be said of "Islamic spirituality." For an overview of some of the contending arguments surrounding the question, see Green (2012, 1-14), Safi (2000), and Sviri (2012). In view of these differences, it seems prudent to avoid terminological dogmatism, and to work with the range of categories at our disposal, recognising the relative advantages and disadvantages of each of them, while, at the same time, clarifying what we mean by our own use of terms. In the present inquiry, I have opted for the somewhat unconventional "contemplative ethics" to highlight the interiorising, reflective, meditative focus of Sufism on akhläq or "character traits" - at least when viewed through the prism of its science of praxis ('ilm al-mu'ämala). This is the dimension of the tradition which usually stands in a complementary (though possibly independent) relationship with its more "mystical" branch of 'ilm al-mukāshafa (science of unveiling). The importance that the cultivation of virtue plays in Sufism was highlighted by Ibn al-'Arabī, when he opened his chapter "on the station of tașawwuf" in al-Futūhāt al-Makkiyya ("The Meccan Revelations") by declaring, "the Folk of the Way of God say that Sufism is good character, and that he who surpasses you in character, has surpassed you in Sufism" (n.d., 2:266). For more on Sufi virtue ethics, see Heck (2006), Khalil (2021), Yazaki (2015), and Zargar (2017). 
hadiths, and the various sayings and aphorisms of the sages, it does not imply, at the same token, an undiscerning meekness or servility before others, much less passive acquiescence before the unjust. After all, when the Prophet was asked to describe the noblest form of jihād, he replied, "a word of truth (haqq) before a tyrant" (Wensinck 1936-1969, h-q-q). And he also said, "the believer does not humiliate himself" (Wensinck 1936-1969, dh-l-l). We also have the saying of the early authority, Yahyā b. Mu'ādh al-Rāzī (d. 258/872), that "to be proud before the one who is proud before you on account of his wealth, is from humility" (al-Qushayrī 2002, 294). Islam, especially when it is seen through the eyes of its Sufi tradition, steers away from extolling the humility of abject self-abasement before others, on the one hand, and denying it the status of a virtue altogether, on the other, but in a way that is different from the middleground of humility proposed by many modern Western ethicists. And this is in part because of the distinction it draws between humility towards God, and towards others. In other words, the nature of how humility is to be embodied will vary not only as one moves from one person to another, but also when one turns from the human other to the divine other. ${ }^{3}$ Yet in all cases, what is to remain consistent is "humility of heart," an interior state that in relation to God requires of the self to recognise its total ontological dependence on Him, and which in relation to the human other, requires restraining the self from feelings of superiority. In both cases, humility is to stand between pride and self-loathing, but in a way that in relation to God may approach self-abasement without entirely collapsing into and becoming fixed in it. Needless to say, the particular manner in which humility is to be internalised and embodied does not easily allow for a single definition of the virtue.

In the following analysis, we begin with (1) an overview of the semantics of humility in the Quraan, the sayings of the Prophet, and Arabic, and then turn to examine (2) the eminence of humility in Sufi ethics, (3) the marks of the virtue, and (4) its dangers. The article ends with an epilogue on what it means to transcend humility altogether, as "the dot under the letter $b \bar{a}$ '." The works upon which this study relies, ranging from those of al-Makkī (d. 386/996), al-Kharkūshī (d. 406/1015 or 407/1016), ${ }^{4}$ al-Qushayrī (d. 465/1072), Ibn al-'Arabī (d. 638/1240) and Rūmī (d. 672/1273) to Ibn 'Abbād (d. 792/139o) and al-Darqāwī (d. 1239/1823) — to name a few — have not been arbitrarily chosen. Instead, they

3 Humility will naturally be embodied differently in one's interactions with students, parents, teachers, the elderly, and of course strangers. Yet in relation to God, all the categories of people above are summoned to embody humility in a strikingly similar fashion-although a certain boldness may be allowed for saints, in lieu of their intimate relation with God.

4 For more on Abū Sacd al-Kharkūshī (Arabisation of "Khargūshī"), see Karamustafa (2007, 65) and Melchert (2010). 
present us with inquiries into key features of the virtue (linguistic, scriptural, theological, philosophical and psychological) in order to help us better understand its complexity. While limitations imposed by the length and scope of the article require the utilisation of a select number of texts, it is hoped that the present contribution will set the stage for further scholarship on approaches to humility in Muslim tradition.

The Semantics of Humility in the Qur'ān, Hadīth Literature, and Classical Arabic

In Islamic ethical literature, a few terms are generally employed to denote humility. The first is $k h u s h \bar{u} \bar{u}^{c}$, from the trilateral $k h$-sh-' root, which as a verb means to be low, humble or submissive, and as a noun may refer to dead, barren land, or low land with dry vegetation (Badawi and Abdel Haleem 20o8, kh-sh-; Lane 1984, $k h$-sh- ). Etymologically khushü $\bar{u}^{c}$ bears some resemblance to the English humility, a word that comes from the Latin humilis, meaning "low," and which itself stems from humus, namely "earth" or "ground" (Baldwin 1911, s.v. "humility"). Derivatives of the kh-sh-' root appear in the Qur'ān on seventeen occasions. In seven, it is used to describe a virtue of the faithful in the world. Thus we read, "Successful indeed are the faithful, who are humble (khäshiün) in their prayers" (Q 23:1-2); "Seek help in patience and prayer. Verily it is hard, except for the humble" (khäshi ün) (Q 2:45); "and Truly among the People of the Book are those who believe in God, and that which was revealed unto you, and that which was revealed unto them, humble (khäshi ìn) before God" (Q 3:199). ${ }^{5}$ Unsurprisingly, Muslim scripture includes khush $\bar{u}^{c}$ among its list of the salvific qualities of pious men and women, alongside faith, devoutness, truthfulness, patience, charity, fasting, chastity and remembrance (Q 33:35). Derivatives of $k h$-sh-' are also used to describe the awe of nature before divine majesty ( $Q$ 59:21), the subduing of voices before the all-Merciful (al-Rahmānn) on the Day of Judgement ( $\mathrm{Q} 20: 108$ ), and the humiliation (as opposed to humility) of the damned in the afterlife (Q 42:45, 54:7, 68:43, 70:44, 88:2). Khushü also designates the ideal response to the Qur'ān as God's word (Q 3:199, 17:109, 57:16). In 59:21 we read, "Had we sent down this Qur'ān on a mountain, you would have seen it brought low (khäshi'an), rent asunder by the fear of God."

5 According to some exegetes, this last verse was revealed about the death of the Christian king who gave asylum to the Muslim refugees sent to Abyssinia by the Prophet (S. H. Nasr et al., eds. 2015, The Study Quran [hereafter SQ]). I have made extensive use of the sQ for my own translations of the Qurān, in some cases, following it word for word. 
The word also appears frequently in the hadith literature, as in the saying of the Prophet, "the best of people are those most humble (akhsha'uhum) before God," or his prayer, "I seek refuge in You ... from a heart that is not humble ( $l \bar{a}$ yakhsha')" (Wensinck 1936-1969, kh-sh- ).

Another key word employed to denote humility in the sources is tawa from $w-d_{-}^{-}$, the verbal root of which has among its meanings "to put down," "place" or "flatten" (Badawi and Abdel Haleem 2008, w- $-\mathbf{-}-$; Lane 1984, w- $-\mathbf{-}-$ ). The root appears twenty-six times in the Quràn, but in none of them is it used to designate humility, at least not in its outward sense. ${ }^{6}$ Tawa $\bar{a} d u^{c}$, literally "self-lowering" or tadhallul (Ibn Manzūr 1997, w- - $^{-}$), does, however, appear frequently in the hadith literature. The Prophet said, "none humbles himself (tawāda'a) before God but that God raises him," and "he who humbles himself (tawāda'a) for God by a rank, God raises him by a rank." There is also a tradition where God asked the Prophet whether he preferred to be a "messenger slave" or a "prophet king." After seeking the counsel of Gabriel, who enjoined him to "humble yourself before your Lord (tawā du 'li-rabbika)," he chose servitude over kingship. Tawā (at least in the Qur'ān and hadìth literature) to explicitly encompass humility before others alongside God, as a social virtue, as in the prophetic instruction to "be humble (tawäda $\bar{u})$, lest none of you boasts over another, or looks upon another with contempt" (Wensinck 1936-1969, w- $d-{ }^{-}$).

Other terms include tadarru' ("pleading humbly") and darā'a ("humble entreaty," "supplication," "submissiveness"), both of which stem from $d-r_{-}^{-}$, which means to "call for help," "entreat," "abase," or "lower oneself." The expression dara'a bihi farasuhu, for example, means that "his horse humbled him," "abased him," or "overcame him." The word dar', literally an "udder," "teat," or "stream of milk from an udder," conveys for some of the classical lexicographers the primary signification of the verbal root, which may be used to refer to the taking by the mouth the dar' of the mother (Badawi and Abdel Haleem 2008, $d-r-$; Lane 1984, $d-r-$ - $)$. In other words, at the centre of the conceptual field created by $d-r$ - 'we encounter the idea of a state of need, want, and powerlessness before another, like a lamb or young animal that in its desire for nourishment, stands entirely at the mercy of its mother-a fitting illustration of the human being's relation to God. In the Qur'ān $\boldsymbol{c}_{-}-\boldsymbol{r}^{-}$' appears eight times. In one verse we read, "And remember your Lord in your soul, humbly (tadarru can) and in awe" (Q 7:205). In his lexicon, Ibn Manz̄ūr (d. 711/1312) explains that the condition of

6 Sufi exegetes often draw out meanings of the Qurān pertaining to the inner, spiritual life, in ways that do not necessarily violate the literal sense of the text (Chodkiewicz 1993a; Sands 2006). 
darā'a here signifies "intensity of poverty and need towards God" (d-r- $)$. And in another verse, we read, "If only when Our chastisement came upon them, they had humbled themselves (tadarra $\bar{u}$ ). Instead, their hearts hardened, and Satan made all they used to do seem fair to them" (Q 6:43). The "hardening" of the heart in the verse reflects a state opposite to that of humility, which is always accompanied by a softened heart. In the Dalāil al-Khayrāt ("Guide to Goodness"), the celebrated poem of praise and prayer upon the Prophet by al-Jazūlì (d. 870/1465), he is reverentially described as șāhib al-ḍarā'a.

We should note that there are some differences of nuance and meaning in the aforementioned terms. As far as the Qurānic use of khush $\bar{u}^{c}$ and $\operatorname{dara}^{\top} a$ are concerned, al-Rāghib al-Ișfahānī (d. 502/1108) states that in most cases, the former is used to describe formal, outward expressions of humility (khush $\bar{u}^{c}$ al-jawärih), whereas the latter is used primarily with reference to inward humility, or humility of the heart-a fact borne witness to by a comparative analysis of how they appear in the Quràn. ${ }^{7}$ To further substantiate this view, al-Iṣfahānī calls attention to the tradition, "if the heart were humbled (dara'a), the limbs would also be humbled (khasha'at)" (2006, kh-sh- ${ }^{-}$). But one has to be careful not to extend this distinction to the broader tradition, since khush $\bar{u}^{c}$ is frequently used to describe inner humility in the texts. Indeed, a hadith states, "if the heart of such a person were humbled (khasha'a), so too would his limbs be humbled (khasha'at)" (al-Qushayrī 2002, 289). ${ }^{8}$ And there is a saying of 'Alī b. Abī Tạalib (d. 40-661), that "khushū' resides in hearts," to which al-Qurțubī (d. 671/1273) adds by way of commentary, that "he who makes a display of $k h u s h \bar{u}$ ' beyond what resides in his heart, has only made a display of compounded hypocrisy" (exegesis of Q 2:45). In fact, al-Qushayrī goes so far as to declare that "they [the masters] have agreed that the locus of khush $\bar{u}$ ' is the heart" $(2002,289)$. The statement does not necessarily negate or undermine al-Ișfahānī's observation, since the latter is based on an almost entirely quantitative analysis of the relational use of the two terms in Muslim scripture.

7 The Qurān describes, through the language of khush $\bar{u}^{\mathrm{c}}$, the lowering of eyes and the subduing of voices (al-Ișfahānī 2006, kh-sh-'; cf. Ibn Manzūur 1997, kh-sh- ). It was this distinction that one modern author had in mind when s/he wrote, "it has been said that khushü pertains to the limbs, while d̦arā'a to the heart" (al-Saḥmarānī et al. 2005, 79 ["Khush ü"]).

8 The hadīth appears in al-Hakīm al-Tirmidhi (d. ca. 295-300/907-912) on the authority of Abū Hurayra (d. 57/678, or slightly later), with a weak chain. See editor's footnote (al-Qushayrī 2002, 289). While the translations of al-Qushayrī's Risāla in the present article are my own, I have liberally made use of the renditions of R. Harris, A. Knysh and B. von Schlegel. As a general rule, I have opted for idiomatic renderings over purely literal ones, to preserve a smoother flow to the English. I have also extensively consulted Zakariyyā' b. Muhammad al-Anșārī's (d. 926/1520) well-known commentary on the Risāla to better grasp the meaning of some of the elliptical aphorisms found in the text. 
As for the difference between khush $\bar{u}^{c}$ and tawāduc, this is less immediately apparent, especially in light of their often synonymous usage in the texts. ${ }^{9}$ For al-Qurțubī, the khāshic (one marked by khush $\bar{u}^{c}$ ) is described as mutawä ${ }^{\prime} i^{c}$ (one characterised by tawādu ${ }^{\prime}$ ). But al-Qurțubī also defines khush $\bar{u}^{c}$ as "a condition of the soul which then manifests itself on the limbs through stillness and tawä $u^{\prime \prime}$ (exegesis of Q 2:45). In other words, tawādu' may be conceived of as an expression of khush $\bar{u}$. This inner/outer distinction seems to find corroboration in the Salwat al-'̈rifin ("Comfort of the Gnostics") of Abu Khalaf al-Ṭabarī (d. ca. 470/1077) ${ }^{10}$ when he states that "khushü is inward, while tawä $u^{c}$ is outward" (2013, [no. 59] 51). And Ibn 'Abbād of Ronda highlights the grammatical basis for this view, at least with respect to tawādu', when he observes that it is the tafäul form of al-da'a ("lowliness"), and that most of these forms involve revealing or displaying a quality (izhār al-șiffa) $(2003,466)$. But this of course does not mean that khush $\bar{u}^{c}$ does not have an outward form eitheras khush $\bar{u}$ - especially when we consider its Qur'ānic usage. Nevertheless, in the classical tradition the accent in conceptions of khush $\bar{u}^{c}$ does seem to lie on the inner state of humility and awe before the grandeur of God. And this is one reason why it is also tied to God-fearingness, as in the saying of al-Ḥasan al-Bașrī (d. 110/728), "khushū' is the perpetual fear of God (khawf) that accompanies the heart" (al-Qushayrī 2002, 288). For Ibn al-'Arabī, this fear of God or khashya (close in meaning to khawf) is itself born of the divine selfrevelation that appears to the human heart, giving birth to khush $\bar{u}$. Or as the Andalusian explains, divine self-disclosure produces knowledge, knowledge produces khashya, and khashya produces khushüc(n.d., 2:193). Knowledge and khashya are the intermediate stages between God's act of revealing Himself and $k h u s h \bar{u}$, as outlined in the tradition, "when He discloses (tajallā) Himself to something, it lowers itself to Him (khasha'a lahu)." And this is one reason why $k h u s h \bar{u}^{c}$ (unlike many of the other human virtues) finds no counterpart

9 Consider that in al-Kalābādhīs (d. 38os/99os) al-Ta'arruf li-Madhhab Ahl al-Tașawwuf ("Introducing the Way of the People of Sufism"), tawāduc is defined by Ruwaym (d. 303/915-916) as "the lowering of hearts before the Knower of the unseen" $(2001,68)$. In al-Qushayrìs Risäla the same definition is now of khushüc and attributed to Junayd (d. 298/910) (2002, 288). In his Kitāb al-Ta' rîfāt ("Book of Definitions"), Jurjānī (d. 816/1413) goes so far as to state that tawa $u^{\prime} u^{\prime}$ and $k h u s h \bar{u}^{c}$ (along with $k h u d \bar{u}^{\prime}$ ) have the same meaning $(2013,82$ [entry on $k h u s h \bar{u}$ ]). Nevertheless, the classical texts do seem to use them with slight variations of nuance, as we see below.

10 The Salwat was authored about two decades after the Risāla of al-Qushayrī, and while it heavily relies on it, there are elements in the text that cannot be easily traced to any other extant sources. This makes it a valuable source for our knowledge of early Sufism. For more on the author, see the comprehensive editorial introduction by Gerhard Böwering and Bilal Orfali in their critical edition of the work. 
in the divine names. "It is from the qualities of created beings," writes Ibn al-'Arabī, "and finds no point of entry into the divinity" (n.d., 2:193). Following this logic, the same may be said of tawäduc. God lowers others while $\mathrm{He}$ Himself remains unlowered. The idea of divine humility and even humiliation that appears in Christianity through the doctrine of the incarnation and suffering of Christ (Baldwin 1911, s.v. "humility") remains relatively alien to Islamic modes of thinking. ${ }^{11}$

Our survey of the semantics of humility could proceed much further. It is sufficient to note that Arabic employs a relatively wide range of terms to denote different aspects of the virtue. The rich conceptual reservoir at the disposal of Muslim thinkers, through an array of available words, allowed them to develop an elaborate system of ethics to identify and describe the subtleties of virtue and vice, even though the precise meaning of the terms that were used may have varied (within certain linguistically acceptable limits) from one authority to another. ${ }^{12}$ Since the semantic dimensions of the subject are not the principal focus of our present inquiry, we shall retain, for the most part, the

11 There can be no question that the different archetypes of spiritual perfection that lie at the heart of the two traditions - in one case, a God who became man only to then suffer humiliation and defeat at the hands of his enemies, and in the other, a man who overcame his Meccan adversaries to eventually assume temporal power-led to the creation of slightly different conceptualisations of humility. In Islam, there was a clear reluctance to allow humility to incline towards self-abasement and humiliation before others in a way that seems present in at least medieval Christian meditations on the virtue. And this is one reason humility in Islamic contemplative ethics comes close to idealisations of the virtue as a middle-ground, as we find in the writings of some modern virtue theorists (such as Nadelhoffer and Wright), even though Sufis and modern ethicists are operating within very different systems of thinking, with diametrically opposed premises and teleological ends in mind. Nevertheless, many of the critiques of humility articulated in Western ethics lose at least some of their force when it comes to Islam, which envisages the quality in a slightly different manner than Christianity. This is not to say that more self-abasing forms of humility as a social virtue did not appear in the faith, as the history of Sufism makes clear. One need not look further than 'Ațtāar's (d. 617/1220) Tadkhirat al-Awliyā' ("Memorial of God's Friends") for such accounts, or to the stories of the Malāmatiyya movement. But these, one may argue, were not representative of the mainstream tradition of tașawwuf, and even when more extreme measures were allowed by the voices of normative Sufism, they would only have been for temporary medicinal purposes, administered perhaps for a patient overcome by feelings of self-importance, haughtiness and pride. This is what Ibn al-Jawzī (d. 597/1201) sometimes failed to appreciate in his Talbis Iblis ("Devil's Delusion") when he went after the aberrations of the Sufisaberrations of the kind that the Sufis were themselves critical of in such works as Abū Nașr al-Sarrāj's (d. 378/988) Kitāb al-Luma ' ("Book of Flashes”).

12 This variation is itself reflected in how translators choose to render different terms. In al-Qushayrì's Risāla, Barbara von Schlegel and Alexander Knysh render khushū" "humility." However, for von Schlegel tawā 
English word in the ensuing analysis, occasionally making use of Arabic terms when necessary, particularly khush $\bar{u}^{c}$ and $\operatorname{tawa} d u^{c}$, the two most frequently employed terms for the concept.

\section{3}

\section{The Eminence of Humility}

One of the reasons for the preeminent place of humility in Islam lies in the weight of its corresponding vice. In the Qur'annic account of creation, after God commanded the angels to bow before Adam, we are told that "they all fell prostrate, except Iblīs; he demurred through pride (istakbara), and so became of the deniers" (Q 2:34). His sin was kibr, the opposite of khushü and tawäduc. Elsewhere in the Qurān, when Satan was interrogated by God for his refusal to bow, he retorted, "I am better than him. You created me of fire, while you created him of clay" (Q 7:12). In other words, why should a being made out of an element that gives light, illuminates, and rises above others, lower and abase itself before a creature made out of clay (țin), which is dark, murky and sinks? This at least was the reasoning imputed to him by some thinkers. Maybudi (d. ca. 520/1126) would explain the gravity of Iblīs's crime in the context of comparing it to the sin of Adam, when he wrote, "both of them turned away from the command, but there is a difference between the two. Adam slipped because of appetite, and Iblīs slipped because of pride. Being prideful is worse than gratifying an appetite. When a sin arises from appetite, there is room for pardon. When a sin arises from pride, faith gets lost in it" (Chittick 2013, 85; cf. Ibn al-Qayyim n.d., 2:345).

Pride, it is worth noting, was also the sin of Pharaoh, who went so far in his affront against God to declare, "I am your lord most high" (Q 79:24), a claim so audacious for Muslims, they are advised to lower their voice in humility upon reciting the verse. The passage continues, "So God seized him with punishment [and made an example of him] in the hereafter and in this life" ( $Q$ 79:25). Some exegetical authorities read the verse, "So God seized him with punishment for the last and the first," with the "first" a reference to his words, "I know of no god for you other than myself" (Q 28:38), and the "last" his claim to lordship in 79:24. Others take the first sin to be his denial of Moses, and agree with the others on the last (sQ, commentary on 79:24-25). What cannot be overlooked is that the cardinal sin of the two archetypes of rebellion and wrongdoing in the Qurān-Iblīs and Pharaoh (figures who embody qualities that every pious

In the context of al-Ghazālī's Kitāb Dhamm al-Kibr wa-l-'Ujb, Rustom translates tawā as "humility" and khushū' as "submissiveness." 
Muslim strives to avoid) — was pride. Indeed, the Prophet warned of its danger when he declared, "he who has even a trace of pride in his heart shall not enter Paradise" (Muslim). When we consider, in addition, the pivotal role that servitude to God ('ubüdiyya) plays in Islamic piety, we can better understand the eminence humility enjoys in Islamic contemplative ethics. ${ }^{13}$

Accounts of the Prophet's humility in the classical texts serve to cement the defining place of the virtue in the faith. In al-Qushayri's chapter on khush $\bar{u}^{c}$ and tawa $\bar{a} u^{\prime}$ in the Risāla, he opens in the customary fashion of many of the early Sufi manuals with scriptural verses followed by hadiths and stories from the Prophet's life. According to one of his companions, "he used to visit the sick, attend funerals, ride a donkey, and accept the invitation of slaves" (2002, 287-288). According to another, "he used to feed his donkey, sweep the house, mend his sandals, patch his clothes, milk the ewe, eat with his servant and labour with him if he was tired. He was not ashamed to carry merchandise home from the market for his family. He would shake the hands of both the rich and poor, and was the first to greet people. He never scorned whatever he was invited to eat - even if it was an offering of dry, unripe dates." The narrator, Abū Sa'īd al-Khudrī (d. 74/693-4), also notes that "he was humble (mutawädi') without abasement (madhalla)," a theme we shall turn to shortly (al-Qushayrī 2002, 291). In another story, we are told that a Bedouin once entered the presence of the Prophet only to then tremble from fear and awe. On seeing this, he told him to be at ease because he was not a king, that he was only the son of a Qurayshī woman who used to eat dried, salted meat. And we cannot, of course, forget the well-known accounts of him expressing his dislike for the companions to rise in his presence.

One of the reasons these stories of the Prophet appear so frequently in Islamic literature is to underscore the following: despite the influence he came to wield over Arabia later in life, he did not succumb to the trappings of pride and self-importance that so often accompany the acquisition of power. Humility might have been forced upon him in his early mission, particularly when he was the object of Meccan scorn and opposition, but he retained it well into the later stages of his life, even after the faith he brought to the Arabs began to gain the upper hand in the peninsula, both as a religious and a political force. In other words, he exercised the virtue out of choice, not compulsion, since humility comes all too naturally for the powerless (as Nietzsche so astutely observed in the Genealogy of Morals). But it takes a feat of self-will

13 On ubüdiyya, see the chapters on the theme in al-Kharkūshì (2006, 171-175) and al-Qushayrī (2002, 364-368). See also Chittick (2008, 218-219) and Chodkiewicz (1993a, 122-129). 
to exercise it when conditions press one in the opposite direction. And this is why when the caliph 'Umar was once asked by his daughter why he continued to subject himself to humbling austerities even as ruler of a rapidly expanding empire, he replied "I take your meaning, but it was in a certain path that I said farewell to two companions of mine," by which he meant the Prophet and Abū Bakr, "and if I turned away from the path with which I walked with them, I should never find them again at journey's end" (Eaton 1985, 136; cf. al-Kharkūshī 2006, 428). Al-Ghazālì (d. 505/1111) alluded along similar lines to the particular merits of humility among those of worldly status when he wrote (citing an earlier saying), "humility in every creature is beautiful, but in the rich it is more beautiful. Pride in every creature is ugly, but in the poor it is uglier" (2018, 23; al-Qushayrī 2002, 293).

A recurring theme in the contemplative literature is that humility is a source of protection. To make claims and aggrandise the self is to open it to humiliation, as the story of Iblīs makes clear. Indeed, according to some traditions he had devoted himself to the worship of God from time immemorial, long before the creation of humanity, to the extent that he was privileged with a special kind of gnosis or ma'rifa. But his insistence that he stood above Adam in rank set the stage for his own tragedy and downfall (Awn 1983). We are also reminded of the story of one of the caliph's men who was surrounded by a flock of people, thanking and praising him during the pilgrimage in such a way that they blocked others, by his orders, from circumambulating the Kaba. Later that same man was seen in Baghdad on a bridge, destitute and begging for money, because the caliph had stripped him of his wealth and honour. When asked why matters had turned around so drastically, he replied, "I was proud in a place where people humble themselves, and so God afflicted me with abasement in a place where people raise themselves" (al-Qushayrī 2002, 295; see also al-Anșāin 2007, 3:31). This was why Maybudī would write, "[n]o one is more unworthy on the face of the earth than he who thinks himself worthy, and no one is more impure than he who thinks he is washed" (Chittick 2013, 137).

Conversely, the authorities also emphasise that to lower the self in humility before God is to set the stage for its exaltation - provided, of course, exaltation is not the goal. In a certain sense, we find here an echo of the words of Christ, "whoever humbles himself shall be exalted" (Matthew 23:12), although the idea, as we saw earlier, permeates the hadìth literature as well (cf. al-Ghazāli $2018,15^{-18)}$. An early figure recounts that in one of the revelations of old, God peered into the souls of the progeny of Adam and found no heart humbler than that of Moses, and for that reason, spoke to him without an intermediary (al-Qushayrī 2002, 292). And according to Fuḍayl ibn 'Iyāḍ (d. 188/803), when God informed the mountains he would address a prophet while he stood 
on top of one of them, they towered up, seeking divine election, all except Mt. Sinai, which lowered itself in humility. And so God revealed Himself to Moses on it (al-Qushayrī 2002, 292). In the Ilāhināmā ("Book of the Divine"), Farīd al-Dīn 'Ațtāar (d. 617/1220) shares a tale that conveys a similar lesson. When Shaykh Abū l-Faḍl al-Sarakhshī (d. 414/1023) ${ }^{14}$ was on his deathbed, his companions informed him that they would bury him in a certain graveyard, to which he protested, "that is the place of the great men of piety." Asked where he preferred to go, he replied, "[o]n the hill where the drinkers, thieves, gamblers and sinners lie. That's where I belong. I don't have the strength to be with those perfect men. Moreover, the sinners there are closer to God's mercy" (Ritter 2003, 315). This was despite the sanctity of the man. His choice came from his knowledge of the saving power of humility, a virtue that demands an awareness of the blemishes of one's own soul. And this is why Ibn 'Ațā' Allāh (d. 709/1309) would declare in one of his aphorisms, "a sin that bequeaths lowliness and need is better than pious devotion that bequeaths a sense of rank and pride" (Hikam, no. 96).

Some of the Sufi texts draw special attention to the value of humilityparticularly khush $\bar{u}$ - in prayer. After all, the Qurān states, "successful indeed are the faithful, who are humble (khāshicūn) in their prayers" (Q 23:1-2). And it also counsels those tried with hardship to "seek help in patience and prayer," recognising that "verily it is difficult, except for the humble (khäshi'̄n)" (Q 2:45). While Abū Ṭālib al-Makkī does not devote a separate chapter to humility in his lengthy section on the "stations of certainty" in the Qütal-Qulüb ("Nourishment of Hearts"), he does address the importance of internalising the quality in his treatment of canonical prayer. Among the requisites of șalāt with khush $\bar{u}^{c}$, for him, are complete and total effacement in God, so that one becomes oblivious to every created thing. As one of the pious said, "for forty years, I was completely unaware, during prayer, of who stood to my right or left. And this was from the time I heard Ibn 'Abbās (d. ca. 68/687-688) declare, 'khushū' in prayer means that the one performing it remain unaware of who it is that stands to his right or left." This condition is the opposite of one who approaches prayer intoxicated, regarding whom the Qurān warns, "do not approach prayer while you are drunk" (Q 4:43) — a state that may also refer to those drunk "with love for the world," or "from their preoccupation with it" (al-Makkī 2005, 3:1206). And this is the kind of prayer of which the Prophet, according to al-Makkī, alluded to when he said, "he who performs two cycles of prayer, while his soul refrains from chattering about any worldly matter, will have all of his previous

14 For more on this little known Khurasānī gnostic, a student of Abū Naṣr al-Sarrāj and teacher of Abū Sa īid b. Abī al-Khayr (d. 440/1049), see the $E I^{3}$ article on him. 
sins forgiven." This is also the kind of prayer which the Prophet advised his companion Anas b. Mālik (d. 93/709) to strive for when he instructed him to "pray as if this is the last prayer," or "farewell prayer," to which al-Makkī adds, "by which he meant, as if one is bidding farewell to himself, farewell to his desires, farewell to his life - to all that is other than his Lord" (2005, 3:1206). For Zakariyyā' al-Anșārī (d. 926/1520), this is one of the reasons why șalät is brought to a formal end by greeting those on the right and left, because it signifies a return from absence $(2007,3: 22)$.

\section{The Marks of Humility}

Many of the Sufi authorities agree that humility has certain marks or signs, and that these cannot be displayed through empty, mechanical gestures, devoid of a corresponding interior state. We find this in the story of a man who was once seen walking with his head down, his shoulders bent forward and tense, in a state of apparent lowliness and dejection. A shaykh who saw this upbraided the man. "Khush $\bar{u}$ ' lies here," he said, pointing to his heart, "not here," pointing to his shoulders. He wanted to impress on him the need to exercise the virtue in such a way that it flowed out naturally, without hypocrisy. After all, Fudayl b. Tyād said of the pious predecessors or salaf, that they "detested seeing on a man marks of humility that surpassed what resided in his heart" (al-Qushayrī 2002, 289; cf. al-Anșārī 2007, 3:23). The reprobation of the shaykh was not to belittle outward signs of the virtue (since humility, as we have seen, comprises both an inward and outward dimension, with the latter being an expression of the former), but to warn him of feigned, misguided mimicries of an otherwise ennobling quality. Genuine outer signs of khushü ${ }^{\prime}$ and $\operatorname{tawa} a \bar{d} u^{\prime}$, for Sufi thinkers, include serving others indiscriminately, not just those whom one esteems, and from whom one may (unconsciously) wish to curry favour. In his commentary on the words of 'Abd Allāh al-Rāzì (d. 353/964-965), that "humility is to abandon making distinctions in service (khidma)," al-Anșārī explains that it means to serve both the slave and free, the rich and the poor, those of high and low social standing $(2007,3: 30)$. In other words, everyone. Conversely, it also means one not deem himself so important so as to expect the recognition, kindness and benefaction of others, through a feeling of entitlement and special self-worth. "Among the signs of its realisation," wrote Ibn 'Abbād of humility, "is an intensification of the desire to have neither rank nor standing among people" $(2003,467)$. And this was at least one of the meanings imputed by tradition to the words of the man, who, when he was asked by al-Shibli (d. 334/946), "what are you?" (as was his custom), replied, "O my master 
(sayyid $\bar{\imath}$ ), the dot under the letter $b \bar{a}$." The answer was accepted by al-Shiblī, "so long as you do not claim for yourself a station" (al-Qushayrī 2002, 294; cf. al-Anșāī 2007, 3:30-31).15

Another mark of the virtue is to think well of others, or have a high estimation of them —what Dhū l-Nūn (d. 245/859) refers to as ta'zịm al-nāṣṣ (al-Ṭabarī 2013, [no. 6o] 52). Instead of seeing others below oneself, one perceives them as superior. And this may be even though they do not have the same marks of piety one finds within oneself, since one's own piety may well be insincere and hypocritical, while the seeming impiety of others may be no more than a veil over genuine sanctity and divine love, or a doorway to repentance, reform and a life of holiness. In other words, outward piety can all too easily be deceiving. ${ }^{16}$ This general attitude, free of contempt and self-righteousness, should in turn lead to an openness to accept truth from anyone, without resistance, even if it goes against one's own opinions. Dhū l-Nūn said, "among the marks of humility [... is ...] to accept the truth (haqq) and counsel (nașiha) from whomever it comes" (al-Ṭabarī 2013, [no. 6o] 52). This implies listening attentively to others, no matter what their rank or position, since truth is truth, and the most unlikely person may well be a source of wisdom, provided one is willing to listen. Moreover, since the divine presence is everywhere, truth cannot but manifest itself from God, who often speaks from behind the curtain of the world, not only through the mouths of saints but also sinners. In other words, behind the secondary causes or $a s b \bar{a} b$ through which the truth appears, in reality, it can only come from the Causer of causes or musabbib $a l-a s b \bar{a} b$, which is all the more reason to give others an ear. And this may be why one of the early Sufis said, "humility is to accept the Truth, from the Truth, for the Truth (al-tawāḍ ' qubūl al-ḥaqq min al-ḥaqq lil-ḥaqq)" (al-Kalābādhī 2001, 68). Closely related to this mark is another one, namely avoiding quarrels and argumentation. Rooted in the subtle desire to always be right, the ego is often driven by an (intellectual) will-to-power-not a desire to share the truth for the good of others, let alone for the truth itself, as much as to impose one's own views on them, and savour the feeling that comes from forcing them to acquiesce, through rhetorical prowess, to one's own beliefs. Al-Qushayrī writes, "from among the signs of humility in the servant of God is that when opposed, angered or rejected, he takes it upon himself to meet it with acceptance" (2002,

15 For more on this fascinating figure from the early tradition, see Avery (2014). For more on the meaning of this exchange, see the epilogue below.

16 As Abū Sulaymān al-Dārānī (d. 215/830) said, "humility is that when you step outside of the door of your home, you do not meet either a believer or disbeliever without recognising that on the Day of Judgement, he may turn out to be better than you" (al-Kharkūshī 2006, 427). 
288; cf. Ibn 'Abbād 2003, 467 [commentary on Hikam no. 239]). Humility often requires silence.

The Sufi authors were acutely conscious in their deliberations on humility of the hidden traps that lay on the road of one who sought to internalise the quality. Among them was the possibility of becoming conscious in oneself of the virtue, which brings us to one of the paradoxes of humility. In his aphorisms, Ibn 'Ațā' Allāh declares, "he who affirms humility in himself is in truth proud, for humility does not arise except out of a sublime state" (Hikam, no. 238). In other words, a truly humble person cannot make a claim to humility (either to himself or others) without arrogating for himself a spiritual rank - an arrogation that amounts to an act of pride, since humility makes (or at least contributes to making) one great. Expressed differently, to lay claim to humility is, in effect, to lay claim to greatness, which is the very opposite of what humility entails. In this respect, humility is unique among virtues in that it is the only virtue of which one cannot claim possession without relinquishing the very possession itself. As strange as it may seem, we simply have to go through the virtues one-by-one to recognise this fundamental truth. One may, for example, acknowledge his compassion without it nullifying his compassion. One may speak of his honesty without such talk rendering him dishonest. One may recognise his generosity, even go so far as to boast of it, without necessarily becoming ungenerous or stingy. But one cannot openly confess, let alone acknowledge, his humility without such an act negating humility altogether. And this is why we may go so far as to say that it is unique among virtues in that its possessor cannot be aware of it within himself, without the awareness nullifying the virtue. When Abü Yazìd (d. 26o/874) was asked "when does a person become humble?" he replied, "when he finds in himself no station or state" (Ibn 'Abbād 2003, 467; cf. al-Sharnūbīi 2014, 227). In other words, when he sees nothing in himself that would confer upon him a spiritual rank. And humility is one such rank.

Another danger in humility is that in the desire to lower the self, one may become obsessed with it, with the obsession easily metastasising into a subtle form of narcissism. As a contemporary Christian authority put, "humility is

17 One of the merits of the commentary on the Hikam by the Azharī scholar 'Abd al-Majīd al-Sharnūbī (d. 1348/1929) is that it synthesises and brings together in an abridged form what is most essential in the earlier commentaries. 
not thinking less of yourself, but thinking of yourself less."18 And this is what separates humility from low self-esteem, since in the latter one's gaze is fixated on the self-usually on its material or worldly failings (typically involving accomplishments, talents, popularity, beauty, intelligence, education, social standing, and wealth). In this regard, low self-esteem often originates in what some psychologists describe as "comparison thinking," where the subject compares what he lacks, or thinks he lacks, with what others have, or appear to have. Indeed, al-Darqāwī warned against the dangers of becoming preoccupied with the insignificance of the self. In one of his letters, he described how a fellow wayfarer came to him and complained, "I am nothing," to which he retorted, "do not say 'I am nothing,' nor, 'I am something' [...] But rather say 'Allāh,' and you will see wonders" $(1998,18)$. In other words, he counselled him to turn his attention away from the self towards God, otherwise he risked descending into a pit of self-loathing and abasement. This condition is contrary to genuine humility, since the virtue lies not so much in a preoccupation with one's faults as much as in a sense of wonder with the splendour of God. And this is why al-Darqāwī replied when he was asked about the soul's cure, "[f]orget it and do not think about it, for he who does not forget his soul (does not forget himself) does not remember God" $(1998,18)$. The Sufi master was simply echoing the words of Dhū al-Nūn, that "he who desires humility should turn his face towards the majesty of God," for "he who gazes at the sultanate of God vanquishes the sultanate of his own ego" (Ibn 'Abbād 2003, 469). It is not enough therefore to say that humility is grounded in self-forgetting-it is a self-forgetting accompanied and made possible by the remembrance and contemplation of God, in the face of whose being everything else vanishes. Humility, in this light, is the response of the soul to the self-revelation or tajalli of God, as Ibn 'Ațā' Allāh declares in one of his aphorisms (Hikam, no. 240), and as we also saw in the meditations of Ibn al-Arabī. It is like a woman who becomes oblivious to all other sounds when she hears a beautiful melody, or a man who forgets himself when he turns his glance towards the full moon. And

18 Often attributed to C. S. Lewis, the words are of the popular American pastor Rick Warren, himself inspired by the penetrating meditations of Lewis. The Oxford Christian apologist's own reflections on the dangers of humility reflect concerns similar to those found in the Islamic texts. In the Screwtape Letters, Lewis has a senior demon counsel a junior one on how to mislead a man through false humility: "All virtues are less formidable to us once the man is aware that he has them, but this is specially true of humility. Catch him at the moment when he is really poor in spirit and smuggle into his mind the gratifying reflection, 'By jove! I'm being humble', and almost immediately pride—pride at his own humility will appear. If he awakes to the danger and tries to smother this new form of pride, make him proud at his attempt" (1996, 69 [Letter no. 14]). 
this is one reason why in Islamic contemplative ethics, humility is positioned as a virtue in between self-loathing and pride, two vices that sprout like weeds in the soil of the heart when watered by an unhealthy fixation on the worth or worthlessness of the self.

This brings us to an issue commonly brought up in contemporary ethical literature on humility. The argument is often made that one of the flaws of the virtue is that it prevents one from acquiring an accurate knowledge of his own talents, skills and self-worth. Recall the words of Hare at the opening of the essay, that humility "for many denotes low self-regard or meekness, and it is hard to see what is beneficial to oneself or society as a whole in a tendency to dismiss whatever strengths one does have." How might one view this objection from the vantage point of Islamic contemplative ethics? The answer, it appears, would be two-fold. First, the soul has its own unique and special worth because God brought it into existence from non-existence, from nonbeing into being, with the intention of opening up for it a pathway to eternal felicity. If the soul had no intrinsic value, God would not have created it to begin with. More importantly, the significance of the soul is predicated on its being made (at least for some authorities) in the image of God, as imago dei, 'ala șüratihi. ${ }^{19}$ Closely intertwined with this reality is another one: that the human form is a repository of the Spirit or rụh breathed into Adam by God (Q 38:72). ${ }^{20}$ The human being is therefore a vessel for something concealed within her, precious beyond measure. When the authorities do encourage the aspirant to castigate the nafs, as they do on occasion, especially in more ascetically inclined literature, ${ }^{21}$ it is to denigrate the lower self or ego that stands in

19 The pronoun in the hadìth which appears in al-Bukhārī (d. 256/870) and Muslim (d. 261/875) (Wensinck 1939-1969, kh-l-q), "Verily God created Adam 'alā șüratihi," can be read in two ways. It may refer to Adam ("according to his form"), in which case it would mean that the primordial human being was created as a fully formed adult. Or it may be interpreted to refer to God ("according to His form"), making Adam imago dei. Ibn al-Arabī and others accepted both interpretations, which is to say, the fully fashioned Adam was formed in the image of God. But what does it mean to be made in the divine form? Ibn al-'Arabì clarifies that it is "according to the form of the name of God," and since the name Allāh is the all-encompassing name, it means that he was created as a repository for the divine names. For an excellent discussion of this hadith, see Chodkiewicz (1993a, 37-39). On the primordial Adam, see al-Futūhạt al-Makkiyya (Ibn al-Arabī n.d., 1:123-124), as well as the opening chapter on him in the Fușūṣ al-Hikam (Ibn al-'Arabī 198o, 48-58). Cf. Genesis 1:27. See also the comprehensive entry on Adam in the Integrated Encyclopedia of the Qur'ān (Iqbal and Ahmad 2013, 99-118, at 102-103), and Melchert (2011).

20 See my discussion of competing interpretations of the nature of the rüh in "Sufism and Quranic Ethics" (2021).

21 "[A]base it," as al-Muhāāibī (d. 243/857) says in one place (of the lower soul), "as God has abased it" (Picken 2011, 182). 
the way of the realisation of the higher self, and not the human being per se, in her totality (since the human self is multileveled). ${ }^{22}$ And even then, it is usually tempered by an emphasis on directing one's attention towards God above all else, through a psycho-spiritual technique that enables a vision of the divine sun to eclipse rather than debase the self.

Second, each human being is privileged, from the general Islamic point of view, with divinely bestowed gifts. To turn a blind eye to them out of fear of pride is to risk falling into another vice, namely ingratitude or kufr al-ni'ma. The Qur'ān after all is replete with passages that draw attention to God's bounties, and the need to be continuously mindful of them. "If you were to count the blessings of God," we read in one passage, "you would not be able to enumerate them" (Q 16:18). And elsewhere the Qurān states, "He has poured upon you His blessings, both manifest and hidden" (Q 31:20).23 But the manner in which the Islamic contemplative tradition directs the human being to safeguard himself from pride over these gifts is by reminding him that they are precisely that — gifts. They are not the fruits of one's own labour or "acquired goods," but bestowed from above, by a power that could take them back as quickly as it conferred them. The Sufi authors refer to this fundamental awareness as "gratitude of the heart," and it is often described as the peg upon which all other forms of thankfulness rest. Ibn al-'Arabī refers to it as al-shukr al-ilmī, or "gratitude of knowledge," because it entails knowledge of the ultimate origin of life's blessings. Of this gratitude he writes, "it is true gratitude (wa-huwa haqq al-shukr). It is to see that the blessing is from God. If you see that it is from God, then you have shown gratitude to Him with true gratitude" (n.d., 2:202). What this means is that although one may have an accurate knowledge of one's own unique gifts, it must be balanced by a corresponding awareness of their origins in divine benefaction, with the latter mitigating against pride. As for spiritual gifts- for divine gifts are after all not just worldly but also religious, not just dunyawì but din̄ - whether they involve faith, understanding, goodness, or the love of God, they too are blessings, and the human being cannot lay claim to them any more than he can to his worldly gifts. And this is why for the Sufi authorities, repentance involves turning away not only from sins, but also from witnessing one's good deeds (ru'yat al-hasanāt) as if they were one's own, in other words, from laying claim to one's piety (Khalil 2018, 91-92). With that said, an important qualification remains, and it is that there is a general push in the tradition to discourage the aspirant from paying attention to early Islam spirituality, and the Qurānic basis of this hierarchy, see Picken (2011). 
his virtues, but not to his worldly blessings. And this is so that the soul may remain satisfied with where it stands in relation to its worldly amenities, but not its spiritual state, out of fear that this may create a loss of himma or aspiration. For this reason, the Sufi authorities insist that the aspirant have rid̄a or satisfaction with her lot in the world, but not with where she stands in relation to God, much less her vices and sins. And this is at least in part because, as we saw earlier, one's own piety may well be insincere, rooted in ostentation and hypocrisy. The veil over one's actual spiritual condition will only be lifted after death (see al-Kharkūshī 20o6, 428). 'Abd al-Wahhāb al-Sha'rānī (d. 973/1565) recounts a story from the life of Junayd (d. 298/910) which illustrates this very point. Once the spiritual master of Baghdad was asked, "who is better, you or a dog?" He replied, "this is a matter that pertains to the unseen, of which none has knowledge but God. If in the end, it is I who enters the Fire, then the dog is better than me. But if in the end, I enter Paradise, then I am better than the dog" (1999, 521).

The final danger in humility is that it may bring with it a meekness or subservience to others, especially the unjust and the overbearing. Here we must return to a distinction drawn earlier between humility before God and, as a social virtue, before others. With respect to the first, the wayfarer should aspire to cultivate the quality in all circumstances, in every state, both outwardly and inwardly. The human being is after all in his nature a slave, an 'abd, a faqir impoverished and needy in relation to God, on whom he depends for everything. As the Qur'ân states, "You are the poor in relation to God" (Q 35:15). But this does not imply debasement or give license to demean and humiliate the self, because not only is he imago dei, the human being is also God's vicegerent on earth (the two ideas being intertwined, since vicegerency or khiläfa is conferred upon him through his capacity to manifest certain qualities of the divine king). It behoves him, therefore, not to betray his own integrity—an integrity and honour to which the Qur'ān draws attention when it states, "We have indeed honoured the children of Adam" ( $Q$ 17:70). This may have been one of the reasons why the Prophet said, "the believer does not humiliate himself."

As for humility in one's relations with others, this remains contingent on who the other is. With the vast majority of people, the authorities emphasise the need to comport oneself with goodwill, charity, deference and humility, both outwardly and inwardly. But there is a certain class of human beings-a small faction that includes the proud and the boastful, even tyrants and oppressors-before whom one is never encouraged to bow in subservience. And if one is forced to indignity by circumstance, one should not deceive oneself into thinking that such abasement amounts to godliness. In fact, those who have courage and strength of bearing are summoned by many of 
the Sufi masters to stand up, if they can, provided the harms do not outweigh the benefits of passively acquiescing to tyranny. ${ }^{24}$ This was certainly one of the meanings of the hadith, that "the best jih äd is a word of justice ('adl) before a tyrant." ${ }^{25}$ And this is why the Prophet is reported to have said, "when you see those who are humble from my community, be humble towards them. And when you see the proud, be proud over them, for that will lower and belittle them" (Ibn 'Ajība n.d., 336 [commentary on Hikam no. 238]; al-Kharkūshī 20o6, 426). And this is also why when one of the gnostics was asked about tawādu, replied, "it is pride before the rich, and self-lowering before the poor (tadhallul lil-fuqarā’)” (al-Kharkūshī 2006, 236; cf. al-Sīijānī 2012, [no. 372] 174). We should also not forget the saying of Yahyā b. Mucādh, which we saw earlier, that "to be proud before the one who is proud before you on account of his wealth, is from humility." However, it should be noted here that pride in response to the haughtiness of others should only be outward, as a form of compassionate tarbiyya or teaching, and must not be allowed to penetrate one's heart, because of its poisonous nature, especially since the proud other may stand in a better relationship with God, even in his moment of pride, due to other potentially saving merits, or, for that matter, one's own vices (be they concealed or not). But what is clear is that in certain conditions humility is to be embodied outwardly in ways that betray conventional notions of the virtue, and that humility can even be turned on its head when the circumstances demand it, and still remain humility. And this is why the virtue in Islamic contemplative ethics amounts to anything but a continuous and undiscerning state of outward self-abasement before everyone, everywhere. Inwardly, however, one must strive to cultivate humility in every state, both with God and with others. And this further highlights the discernment necessary for one to know how to manifest the virtue in each moment, as ibn al-waqt. ${ }^{26}$

24 And if one is forced by circumstance to endure the oppression of another in a state of powerless debasement, the virtue to be exercised here is patience (sabr), perhaps the most notable Qurānic archetype of which is Āsiya the wife of Pharaoh (see Q 66:11).

25 There are slight variations of this tradition in the hadith literature. See sunnah.com.

26 In the history of Sufism, one was often directed in these matters by the wisdom of spiritual teachers, who functioned, as it were, as physicians of the soul, counselling the aspirant on matters in which his own discernment was not refined enough for him to guide himself. 
The Buddhist philosopher Nāgārjuna (d. 250) once said of the doctrine of emptiness, that not only was it an antidote to the suffering brought on by misguided beliefs, it was so elusive to normal modes of thinking, that to grasp it correctly was like grasping a poisonous snake-any errors would be fatal. At some risk of exaggeration, one might make a similar argument for humility in Islamic contemplative ethics. As we have seen, a zealous and unthoughtful attempt to embody the virtue can lead one down a path of prideful narcissism as easily as it can towards self-denigration and loathing. And this is one reason why it remains so difficult to provide a simple, straightforward, and even formulaic definition of what precisely humility is - a fact made all the more evident when we consider the range of definitions given to the virtue in the texts of tașawwuf, all the way from al-Muhạsibī in the gth century to al-Sharnūbī in the 2oth, with everyone from al-Ghazālī, Ibn 'Abbād, and al-Darqāwī in between. But there are a few consistent features of the virtue that we can identify with some measure of confidence.

To begin, as a religion that places 'ubüdiyya or servitude at the centre of piety, at the heart of the relation between God and the human being, humility serves as a gateway to the internalisation of other virtues. ${ }^{27}$ Muslims are acutely aware that among the most important titles of the Prophet was 'Abd Allāh, "the servant of God," and that in the rites he is referred to as 'abduhu wa-rasūluhu, "His servant and His messenger." To emulate the Sunna or wont of the Prophet is to aspire to obtain the perfection of ubüdiyya, and ubüdiyya cannot but entail, for self-evident reasons, khush $\bar{u}^{c}$ and tawāduc Moreover, to the extent that pride appears as the cardinal sin of Pharaoh and Iblīs in the Qurāntwo archetypes of wrongdoing in Muslim consciousness-it stands to reason that just as pride is a source of sinfulness, humility stands at the root of virtue. Second, our analysis of the semantic field of humility in Arabic through a survey of key words employed to denote the concept in the Qurān and hadìth literature made it clear that humility involves "self-lowering." However, this lowering is guided in the direction of effacement (in the mystical sense) rather than self-denigration, particularly in light of the emphasis the Sufi authorities often place on forgetting the self by remembering God. Nevertheless, this push

27 For a similar argument made in the context of modern Jewish ethics, through an appeal to the teachings of the rabbis, see Green (1973). For a secular approach that places humility at the centre of the virtues, as a "foundational virtue" that makes the completion and perfection of the other virtues possible, see Nadelhoffer and Wright (2017a, 328-329). 
towards effacement is usually preceded by becoming more acutely aware of one's own sins, vices and moral failings-a process set in motion by repentance, which marks the beginning of the spiritual life.

Third, while many of the virtues find a correspondence in the divine names, such as patience (șabr), gratitude (shukr), compassion (rahma), returning (tawba), forgiveness (maghfira), benevolence (lutf) and gentleness (hilm), khush $\bar{u}^{\prime}$ and tawā $u^{\prime} u^{\prime}$ do not. They are, after all, qualities that signify a state of poverty and need before God, who is Himself free of want. Fourth, humility is a state of protection. To abstain from making claims serves to safeguard the soul from humiliation at the hands of God and through the wiles of the devil. As Sahl al-Tustarī (d. 283/896) put it, "Satan does not approach one who lowers his heart in humility" (al-Qushayrī 2002, 288). Conversely, to make claims to grandeur is to set the stage for one's fall, as the stories of Iblīs and the Pharaoh in the Qur'ān illustrate. Fifth, as subtle as the virtue is, particularly because it is first and foremost a virtue of the heart, there are nevertheless certain marks or signs of the quality. With respect to others, it requires above all service (khidma), thinking well of people (husn al-zann), a certain openness of mind, as well as an absence of feelings of entitlement, and no desire to be treated as if one were special and unique. It also includes the absence of what we might call a "saviour complex," the presumption that others stand in need of oneself because of one's special worth. And in relation to God, it brings with it an acknowledgement of one's total dependence on Him, not only for one's being, but also for all of life's gifts. It also entails 'ibāda (related to 'ubüdiyya), which is to say, devotion, worship, and overall servitude. In fact, we might even say that ibāda of the divine other finds its counterpart in khidma of the human other: in both, one gives of oneself to another in humility, since humility is rarely if ever self-contained.

Sixth, humility is a virtue that cannot survive in isolation without creating imbalances within the soul. Indeed, in light of the Sufi conception of the harmony of the virtues, no single virtue can exist in its fullness on its own. While humility might help generate other virtues, it is itself completed and perfected through the presence of a range of other akhlāq or character traits essential to Muslim piety. Finally, we should reiterate that humility stands between two sets of vices: pride, self-admiration, and conceit on the one hand, and selfloathing, self-denigration, and humiliation on the other. In relation to God, however, humility may incline towards self-abasement, but the danger in this inclination - one that may lead to an unhealthy fixation on the self, loss of self-respect and integrity, and an invitation to the contempt of others-was well recognised by the authorities, whence their continuous emphasis on turning one's attention to God through remembrance. 

and Self-Loathing

There is one final feature of humility that we did not get a chance to explore, due to both constraints of space and the restricted aims of our present analysis, but there have been enough intimations of this theme in our discussion so far to see how it naturally develops out of the logic of Sufi ethics. In the ascent of the wayfarer (an ascent which begins with turning away from sins, vices, and a potentially grandiose sense of self-importance), the seeker eventually reaches a point where humility becomes a vice. Humility, after all, involves putting the self in its place, in relation both to God, and to others. But for those who are entirely absorbed in the contemplation of God, such a concern itself cannot but eventually become an impediment to the realisation of the highest aims of the path. And this is why humility reaches its perfection when the aspirant abandons it altogether, like a raft that is left behind upon arriving at the shore, so that one no longer turns back even to look at it. Junayd appeared to have this idea in mind when he declared, "humility in the eyes of the people of divine oneness is pride (al-tawā ư 'ind ahl al-tawhìd takabbur)" (al-Kharkūshī 2006, 425; cf. al-Ghazālī 2018, 23), ${ }^{28}$ because it would be prideful to lay claim to the existence of something that, upon arrival at the divine court, fades away into oblivion, and that in relation to God has ultimately no existence of its own. And this was also why Rūmī declared that the greatest act of pride a person could ever commit was to claim existence itself, alongside God, even if that existence amounted to taking on the mantle of servitude:

Anyone who says 'I am God's servant' predicates two existences, his and God's, while the one who says 'I am God' nullifies himself — that is, he gives up his own existence as naught. It is said that 'I am God' means, 'I do not exist; everything is He. Existence is God's alone; I am utter, pure nonexistence; I am nothing. There is more humility in this than any claim to greatness, but people do not comprehend. When a man acknowledges his servitude to God, he is aware of his act of being a servant. It may be for God, but he still sees himself and his own act along with seeing God. He is not 'drowned;' drowned is he in whom there is no motion or action but whose movement is the movement of water. A lion chases a gazelle.

28 Of Junayd's words, al-Ghazālī writes, "perhaps he meant that the one trying to humble himself (mutawādi $i)$ affirms himself and then humbles it, whereas the person of [divine] oneness (muwahhid) does not affirm his self, nor does he see it as a thing that he should humble or elevate" $(2018,23)$. 
The gazelle flees from the lion. There are two existences, the lion's and the gazelle's. When the lion catches the gazelle and the gazelle faints in fear under the lion's wrathful paw, then there remains only the lion's existence; the gazelle's being is obliterated (1999, 45-46).

In other words, at the highest stages of the soul's ascent, the soul must forget itself altogether, transcending its own existence as a servant, as an ' $a b d$, and all the virtues associated with it. Expressed differently, at the highest levels 'ubüdiyya shifts from servitude to effacement and annihilation, collapsing, in effect, the lord-servant dichotomy altogether, leaving behind the existence of the One, in its solitude, without co-partner.

Earlier we came across the account of the man who said to Shiblī, "My master, I am the dot under the letter $b \bar{a}^{\prime}$," an answer that was accepted by him. From one point of view, the moral of the story could indeed be interpreted to mean that he had reached a stage where he felt that there was nothing special about him, no rank to spiritual greatness, nothing. The dot after all is placed beneath the $b \bar{a}$, like the humble person who refuses to see himself as superior to anyone else. And this dot, no less importantly, lies below a letter that in the mystical symbolism of Arabic letters, sometimes represents creation. However, we may also read his response from another vantage point, symbolising not so much humility but effacement, obliteration, and immersion in a realitythe dot or nuqta - that symbolises God, as the point out of which all worlds emerge, like concentric circles, or from which all letters originate and come to an end. ${ }^{29}$ From this "higher" perspective, we come to an understanding of humility that moves well beyond the parameters of the debates we usually find in modern Western virtue theory. Here humility is no longer a quality placed somewhere in between pride and self-loathing, but beyond them both, in a subject who, effaced of all traces of selfhood, stands at "the station of no station" (cf. Chodkiewicz 1993b, 37). And this may have been the deeper meaning behind Shibli's reason for accepting the man, "so long as you do not claim for yourself a station."

29 On Islamic letter symbolism, see Schimmel (2011, Appendix 1 ["Letter Symbolism in Sufi Literature"]), and Nasr (1987, Chapter Two ["The Spiritual Message of Islamic Calligraphy"]). On Ibn 'Ațā̄' Allāh's meditations on the meaning of the nuqța, hamza and alif, see the excellent translation by Khalid Williams of his al-Qașd al-Mujarrad fìMa'rifat al-Ism al-Mufrad (2018, 38-43). For the original Arabic, see Ibn 'Ațā' Allāh (2001, 67-72). 


\section{Bibliography}

al-Anșārī, Zakariyyā'. 2007. Natā’ij al-Afkār al-Qudsiyya fỉ Bayān Ma'ānì Sharḥ al-Risāla al-Qushayriyya. Beirut: Dār al-Kutub al-'Tlmiyya.

Avery, Kenneth. 2014. Shibli: His Life and Thought in the Sufi Tradition. Albany: State University of New York Press.

Awn, Peter. 1983. Satan's Tragedy and Redemption: Iblīs in Sufi Psychology. Leiden: Brill.

Badawi, Elsaid M. and Muhammad Abdel Haleem. 2008. Arabic-English Dictionary of Qur'anic Usage. Leiden: Brill.

Baldwin, James, ed. 1911. Dictionary of Philosophy and Religion, 3 vols. New York: MacMillan \& Company.

Button, Mark. 2005. "'A Monkish Kind of Virtue'? For and Against Humility." Political Theory 33(6): 840-868.

Chittick, William. 2008. "Worship." In The Cambridge Companion to Classical Islamic Theology, edited by Timothy Winter, 218-236. Cambridge: Cambridge University Press.

Chittick, William. 2013. Divine Love: Islamic Literature and the Path to God. New Haven: Yale University Press.

Chodkiewicz, Michel. 1993a. An Ocean Without Shore: Ibn Arabī, the Book, and the Law, translated by David Streight. Albany. State University of New York Press.

Chodkiewicz, Michel. 1993b. Seal of the Saints: Prophethood and Sainthood in the Doctrine of Ibn 'Arabī, translated by Liadain Sherrard. Cambridge: Islamic Texts Society.

al-Darqāwī, Mawlāy. 1998. Letters of a Sufi Master, translated by Titus Burckhardt. Louisville, KY. Fons Vitae.

Eaton, Gai. 1985. Islam and the Destiny of Man. Albany: State University of New York Press (in conjunction with ITS).

al-Ghazālī, Abū Hāamid. 2018. On Condemnation of Pride and Self-Admiration (Kitāb Dhamm al-Kibr wa-l-'Ujb), translated by Mohammed Rustom. Cambridge: Islamic Texts Society.

Green, Nile. 2012. Sufism: A Global History. Malden, MA: Wiley-Blackwell.

Green, Ronald. 1973. "Jewish Ethics and the Virtue of Humility." Journal of Religious Ethics 1: $53-63$.

Hare, Stephen. 1996. "The Paradox of Moral Humility." American Philosophical Quarterly 33(2): $235^{-241 .}$

Heck, Paul L. 2006. "Mysticism as Morality:The Case of Sufism." The Journal of Religious Ethics 43(2): 253-286.

Hodgson, Marshall. 1974. The Venture of Islam: Conscience and History in a World Civilization, 3 vols. Chicago: University of Chicago Press. 
Ibn 'Abbād. 2003. Sharḥal-Hikam al-'Ațāinyya, edited by Muḥammad Riḍā b. Muhammad

Bashīr al-Qahwajī. Damascus: Dār al-Farfūr.

Ibn 'Ajība. n.d. İqāz al-Himam fi Sharh al-Hikam. Amman: Dār al-Fikr.

Ibn al-'Arabī. 1980. Fuṣuṣ al-Hikam, edited by Abū l-'Alā' 'Afîfì. Beirut: Dār al-Kitāb al-'Arabì.

Ibn al-'Arabī. n.d. Al-Futūhāat al-Makkiyya. Beirut: Dār Ṣādir (reprint of standard Cairo edition).

Ibn 'Ațā' Allāh. 2002. al-Qașd al-Mujarrad fı Ma'rifat al-Ism al-Mufrad, edited by Maḥmūd Tawfīq al-Hakīm. Cairo: Maktaba Madbūlī.

Ibn 'Ațā' Allāh. 2018. The Pure Intention: On Knowledge of the Unique Name, translated by Khalid Williams. Cambridge: Islamic Texts Society.

Ibn Manẓūr. 1997. Lisān al-'Arab, edited by Muhammad 'Abd al-Wahhāb. Beirut: Dār al-Ihyā' al-Turāth al-'Arabī.

Ibn Qayyim al-Jawziyya. n.d. Madārij al-Sālikin. Beirut: Dār al-Kutub al-'Ilmiyya.

Iqbal, Muzaffar and Naseer Ahmad. 2013. "Ādam." In Integrated Encyclopedia of the Qur'ān, edited by Muzaffar Iqbal et al., 99-118. Alberta: Center for Islamic Sciences. al-Iṣfahānī, al-Rāghib. 2006. Mufradāt Alfāza al-Qur'ān, edited by Najīb al-Mājidī. Beirut: Al-Maktaba al-'Așriyya.

al-Jurjānī. 2013. Kitāa al-Ta'rīfāt, edited by Maḥmūd Ra’fat al-Jammāl. Cairo: alMaktaba al-Tawfīqiyya.

al-Kalābādhī. 2001. Al-Ta`arruf li-Madhhab Ahl al-Taṣawwuf, edited by Yuhannā Ḥabīb Ṣādir. Beirut: Dār Șādir.

Karamustafa, Ahmet T. 2007. Sufism: The Formative Period. Berkeley: University of California Press.

Khalil, Atif. 2015. "On Cultivating Gratitude in Sufi Virtue Ethics." Journal of Sufi Studies $4(1-2): 1-26$.

Khalil, Atif. 2018. Repentance and the Return to God: Tawba in Early Sufism. Albany: State University of New York Press.

Khalil, Atif. 2021. "Sufism and Qurānic Ethics." In The Routledge Handbook on Sufism, edited by Lloyd Ridgeon, 159-171. London: Routledge.

al-Kharkūshī. 20o6. Tahdhīb al-Asrār, edited by Sayyid Muhammad 'Alī. Beirut. Dār al-Kutub al-'Ilmiyya.

Lane, Edward. 1984. Arabic-English Lexicon. Cambridge: Islamic Texts Society.

Lewis, C. S. 1996. The Screwtape Letters. New York. HarperOne.

al-Makkī, Abū Ṭālib. 2005. Qūt al-Qulūb, edited by Maḥmūd Ibrāhīm Muhammad al-Riḍwānī. Cairo: Dār al-Turāth.

Melchert, Christopher. 2010. "Khargūshī, Tahdhīb al-Asrār." Bulletin of the School of Oriental and African Studies 73/1: 29-44.

Melchert, Christopher. 2011. "God Created Adam in His Image." Journal of Qur'ānic Studies 13: 113-124. 
Nadelhoffer, Thomas and Jennifer Cole Wright. 2017a. "The Twin Dimensions of the Virtue of Humility: Low Self-Focus and High Other-Focus." In Moral Psychology: Virtue and Character, vol. 5, edited by Walter Sinnott-Armstrong and Christian B. Miller, 309-342. Cambridge, MA: MIT Press.

Nadelhoffer, Thomas, Jennifer Cole Wright et al. 2017b. "Some Varieties of Humility Worth Wanting." Journal of Moral Philosophy 14: 168-20o.

Nasr, S. H. et al., eds. 2015. Study Quran: A New Translation and Commentary. New York: HarperCollins.

Nasr, Seyyed H. 1987. Islamic Art and Spirituality. Albany: State University of New York. Picken, Gavin. 2011. Spiritual Purification in Islam: The Life and Works of al-Muhāsibī. London: Routledge.

al-Qurțubī. n.d. al-Jāmic li-Aḥkām al-Qurāān. Tafsir.com.

al-Qushayrī. 199o. Principles of Sufism, translated by Barbara R. Von Schlegell. New York: Mizan Press.

al-Qushayrī. 200o. The Risalah: Principles of Sufism, translated by Rabia T. Harris. Chicago: ABC International.

al-Qushayrī. 2002. Al-Risāla, edited by 'Abd al-Ḥalīm Maḥmūd and Maḥmūd b. Sharīf. Damascus: Dār al-Farfūr.

al-Qushayrī. 2007. Al-Qushayrì's Epistle on Sufism: al-Risala al-Qushayriyya fi Ilm al-Tașawwuf, translated by Alexander Knysh. UK. Garnet Publishing.

Richards, Norvin. 1988. "Is Humility a Virtue?" American Philosophical Quarterly 25(3): 253-259.

Ritter, Hellmut. 2003. The Ocean of the Soul: Men, the World and God in the Stories of Farid al-Din 'Attar, translated by John O'Kane with the editorial assistance of Bernd Radtke. Leiden: Brill.

Rūmī, Jalāl al-Dīn. 1999. Signs of the Unseen: The Discourses of Rumi (Fīhi Mā Fīhi), translated by M. Thackston, Jr. Boston: Shambhala.

Safi, Omid. 20oo. “Bargaining with Baraka: Persian Sufism, 'Mysticism,' and Pre-Modern Politics." Muslim World 90: 259-287.

al-Saḥmarānī, As'ad et al. 2005. Mawsūáat al-Taṣawwuf. Beirut: Dār al-Nafāis.

Sands, Kristin Zahra. 2006. Șüfi Commentaries on the Qur'ān in Classical Islam. New York: Routledge.

Schimmel, Annemarie. 2011. Mystical Dimensions of Islam. Chapel Hill: University of North Carolina Press.

al-Sha'rānī, 'Abd al-Wahhāb. 1999. Lațāîf al-Minan wa-l-Akhlāq, edited by Sālim Mușțafā. Beirut: Dār al-Kutub al-'Ilmiyya.

al-Sharnūbī, 'Abd al-Majīd. 2014. Sharh Ibn 'Ațā' Allāh al-Iskandarī. Damascus. Dār Ibn Kathīr.

al-S̄̄jān̄ī, Abū l-Ḥasan. 2012. Sufism, Black and White: a Critical Edition of Kitāb al-Bayāḍ wa-l-Sawād of Abū l-Hasan al-Sīrjānī, edited by Bilal Orfali and Nada Saab. Leiden: Brill. 
Sviri, Sara. 2012. "Sufism: Reconsidering Terms, Definitions and the Processes in the Formative Period of Islamic Mysticism." In Les maîtres soufis et leurs disciples, edited by Geneviève Gobillot and Jean-Jacques Thibon, 17-34. Beirut: IFPo.

al-Ṭabarī, Abū Khalaf. 2013. The Comfort of the Mystics: A Manual and Anthology of Early Sufism (Salwat al-'Árifin), edited by Gerhard Böwering and Bilal Orfali. Leiden: Brill. Wensinck, A. J. 1936-1969. Concordance et Indices de la Tradition Musulmane, 8 vols. Leiden: Brill.

Yazaki, Saeko. 2015. "Morality in Early Sufi Literature." In The Cambridge Companion to Sufism, edited by Lloyd Ridgeon, 74-97. Cambridge: Cambridge University Press. Zargar, Cyrus. 2017. The Polished Mirror: Storytelling and the Pursuit of Virtue in Islamic Philosophy and Sufism. London: Oneworld Academic. 